\title{
NUMERICAL PREDICTION OF THE STRENGTH OF A THIN- WALLED PIPE LOADED WITH INTERNAL PRESSURE AND AXIAL TENSION TAKING INTO ACCOUNT ITS ACTUAL DIMENSIONS
}

\author{
Halyna Kozbur; Oleh Shkodzinsky; Lesia Dmytrotsa
}

\author{
Ternopil Ivan Puluj National Technical University, Ternopil, Ukraine
}

\begin{abstract}
Summary. If a thin-walled pipe loaded with internal pressure and tension allows the appearance of plastic strains takes place, then the uniform plastic stability loss with the emergence of a local plastic deformation zone is considered the limit state, the corresponding stresses are considered as the limit ones. Correct prediction of the stress-strain state at the moment of strain localization requires taking into account the actual size of the loaded pipe and the calculation of true stresses. The article proposes the implementation of the method of predicting the limit values of true stresses that appear in the pipe at different ratios of internal pressure and axial tension. The physical and mechanical properties of the material, the type of stress state and the change in the actual dimensions of the loaded pipe are taken into account. For two grades of steels (carbon steel 45 and alloy steel $10 \mathrm{MnH} 2 \mathrm{MoV}$ ), an increase in the calculated strength threshold is shown with an insignificant additional load of a pipe loaded with pressure and axial tension. Analysis of the results showed that it is possible to establish a balance between the actual geometry of the element and the load, which will solve the problem of finding the optimal ratio of «weight-strength», important for practical applications in aircraft, rocket and mechanical engineering. The proposed method for finding the limiting values of actual stresses makes it possible to calculate a realistic safety factor and make improved engineering solutions at the design and operation stages of structural elements; to increase the efficiency and safety of using pipeline and shell-type saving systems.
\end{abstract}

Key words: ultimate strength, actual ultimate strength, ultimate stress, the uniform plastic stability loss, localization of strains.

https://doi.org/10.33108/visnyk_tntu2020.04.011

Received 26.11.2020

Problem statement. The accurate prediction of maximum load (burst pressure, fracture pressure) is critical for the engineering design, assessment of integrity and on-line control of oil- and gas pipeline and other vessels under internal pressure [1]. Thus, the study of strainstress state of tubes and containers under combined load conditions is quite important.

Analysis of the known results of the study. As it is shown in [2-6], the influence of axial tension on loading capacity of main pipelines is quite essential. In papers $[7,8]$ some experimental research and theoretical models to determine the stress state impact on the pipes loading capacity has been proposed. Based on the Mises criterion, Updike and Kalnins [9] developed a general mathematical model for stress strain and internal pressure limit values forecasting for axially symmetric thin wall vessels. It was found that calculated fracture pressure causing the local plastic deformations has resulted in higher values compared to the experimental ones.

A great number of analytical and empirical equations are known to be used for pipelines and vessels limit pressure predicting. Nevertheless, it is very difficult to calculate the exact value of fracture pressure and to estimate the accurateness of these equations. The problem of determining the real ultimate stress and ultimate strength factors values hasn't been studied properly. Most studies haven't taken into consideration the material strengthening and the change of patterns size under load. Nominal stress is assumed lower the liquidity limit at design of heavy loaded shell-type structures like reactors bodies, collector bodies, steam generators 
and their elements. Though, some plastic deformation is quite allowable for the elements operating under intense short-term single load conditions. At a certain ultimate level of stress the structural element either loses its plastic resistance or undergoes plastic deformation localization. In both cases the structural element loses its further functionality dealing with shape and size change. Thus, one should be able to calculate real stress taking into account these changes to predict stress-strain state of the element at the moment of the uniform plastic stability loss as accurate as possible. In case when plastic deformation is allowed to be occurred the correct assessment of limit stress is especially important preceding the moment of the uniform plastic stability loss resulting in local deformation area appearance and further ductile fracture of the structural element. The analytical review of literary sources has shown that the problem of real stress forecasting in loaded structural elements at the moment of plastic deformation localization hasn't been studied properly. The conventional existing models and methods do not take into account the material properties, a type of stress state and a change of actual size of loaded structural elements in the complex restricting the areas of their use. At the same time, the continuous increase of cost-efficiency, structure efficiency and performance safety requirements has made the task of improvement of analytical-calculation approach to ultimate states of metal materials forecasting under complex stress state very important and quite urgent.

The paper purpose is to introduce a new technique of ultimate states forecasting for thin-walled pipes loaded with internal pressure and strain and to analyze the influence of physical-mechanical properties of the material, pipe geometry and a kind of stress condition on the values of actual stress and real force factors at the moment of local plastic deformations occurred.

Problem setting. If a structural element under loading allows some plastic strains occurred then the correct estimation of ultimate stresses at the moment of the uniform plastic stability loss resulting in local strain area appearance and further ductile fracture of the structural element will be necessary. In the area of large plastic strains the change of the element size will be important. That is why it will be worth saying about the real strength limit whose prediction requires taking into account the true size of loaded element and true stress-strain curve building. The calculation of ultimate values of true stresses at the moment of strains localization under uniaxial strain conditions is based on the use of Swift-Marceniak criterion and analytical dependence $\tilde{\sigma}=d \tilde{\sigma} / d \varepsilon$ between true stresses and tangent modulus in true stresses use. In the papers $[10,11]$ the criterion of the uniform plastic stability loss was offered to use for ultimate pressure prediction in thin-walled pipes. Analytically the moment of the uniform plastic stability loss in this case is described by the formula $\tilde{\sigma}=\frac{1}{2} d \tilde{\sigma} / d \varepsilon$ containing a correcting multiplier $1 / 2$ at the tangent modulus $d \tilde{\sigma} / d \varepsilon$. The authors are explaining the appearance of a correcting multiplier by the loaded element geometry impact.

The algorithm implementation to find the ultimate values of true stresses occurring at the moment of the uniform plastic stability loss in the pipe loaded simultaneously by internal pressure $\mathrm{q}$ and strain $\mathrm{N}$ has been proposed in the study under discussion. The main analytical dependencies of the method under discussion have been obtained in [12].

As a result the following equation was obtained due to the development of summarized methods of true stresses prediction in the pipe at the beginning of strain localization in [13]

$$
\tilde{\sigma}=\mu \cdot d \tilde{\sigma} / d \varepsilon
$$


where $\mu-$ a correcting multiplier taking into account the physical-mechanical properties of the material, stress state type and element geometry as a whole set. The limit values of equivalent deformations and real equivalent stresses in the pipe walls at the moment of strain localization are found as coordinates of the point of intersection of real deformation curve $\tilde{\sigma}(\varepsilon)$ and the curve of the right - hand side of the formula (1).

The general algorithm of predicting method of strength limit of thin-walled cylindrical pipe with cupped ends loaded by internal pressure $\mathrm{q}$ and axial strain $\mathrm{N}$, and determination of limit values of strength factors is formed from the task sequence:

I) finding the constant $\mathrm{p}$ by the initial stress-strains curves built for several values $k=\sigma_{z} / \sigma_{\theta}$ at the simple stress and building of generalized stress-state curve; coordinates;

II) determination of the dependence between true stresses and strains in equivalent

III) determination of the true ultimate stresses in equivalent coordinates;

IV) calculating the limit values of internal pressure $q$ and tension $\mathrm{N}$.

Analysis of numerical results. We have used the prediction technique of metal strength true limits for thin-walled cylindrical pipes made of two structural materials:

- structure carbon-based high-quality steel 45 [14];

- heat resistant alloy steel $10 \mathrm{MnH} 2 \mathrm{MoV}[15]$.

The loading took place by trajectories $\sigma_{z}=k \sigma_{\theta}$ at different values $\mathrm{k}$.

In [16] the technique has been described which allowed to predict the true stresses at the moment when local plastic deformations appeared. The technique has been used for thin-walled pipe of wall thickness $\mathrm{h}=2,5 \mathrm{~mm}$ and external diameter $\mathrm{d}=65 \mathrm{~mm}$ made of steel 45 . The results of the experiment under discussion have been given as circular $\left(\varepsilon_{\theta}\right)_{i},\left(\sigma_{\theta}\right)_{i}$ and axial $\left(\varepsilon_{z}\right)_{i}$, $\left(\sigma_{z}\right)_{i}$ stresses and strains for $\mathrm{k}=0 ; 0,5 ; 1 ; 2$. The points have been chosen for which the condition was satisfied $\min \left(\left(\varepsilon_{z}\right)_{i},\left(\varepsilon_{\theta}\right)_{i}\right) \geq 1 \% \quad(i=\overline{1, n}$, where $\mathrm{n}=30)$.

Having set the values $\left(\varepsilon_{\theta}\right)_{i},\left(\sigma_{\theta}\right)_{i},\left(\varepsilon_{z}\right)_{i},\left(\sigma_{z}\right)_{i}$ equivalent stresses and deformations are found by formulae:

$$
\begin{gathered}
\left(\sigma_{e q}\right)_{i}=\frac{p}{2}\left[\frac{\left|\left(\sigma_{z}\right)_{i}-\left(\sigma_{\theta}\right)_{i}\right|^{p}+\left|\left(\sigma_{\theta}\right)_{i}\right|^{p}+\left|\left(\sigma_{z}\right)_{i}\right|^{p}}{2}\right]^{\frac{1}{p}}, \\
\left(\varepsilon_{e q}\right)_{i}=\frac{p}{2(p+1)}\left[\frac{\left|\left(\varepsilon_{z}\right)_{i}-\left(\varepsilon_{\theta}\right)_{i}\right|^{p}+\left|\left(\varepsilon_{\theta}\right)_{i}-\left(\varepsilon_{r}\right)_{i}\right|^{p}+\left|\left(\varepsilon_{z}\right)_{i}-\left(\varepsilon_{r}\right)_{i}\right|^{p}}{1 / 2}\right]^{\frac{1}{p}} .
\end{gathered}
$$

Radial stresses were neglected according to the assumptions of the theory of thin-walled shells, i.e. $\left(\sigma_{r}\right)_{i}=0$. Under simple loading conditions the correlation between circular and axial deformations looks like $\varepsilon_{z}=n \varepsilon_{\theta}$. Radial deformations $\left(\varepsilon_{r}\right)_{i}$ were linked with circular and axial conditions of material incompressibility: 


$$
\left(\varepsilon_{r}\right)_{i}=1-\frac{1}{\left(1+\left(\varepsilon_{z}\right)_{i}\right)\left(1+\left(\varepsilon_{\theta}\right)_{i}\right)} .
$$

The values of parameter $\mathrm{p}$ were chosen discretely from the interval $(1 ; 2)$ with a step 0,01. For the given set of points the Pearson correlation coefficient $r$ and variation coefficient $\mathrm{CV}$ have been calculated. The Pearson correlation coefficient maximums are correlated with minimums variation coefficient. As a parameter optimum $p$ the value was chosen for which $r_{\max }$ was reached. For steel $4599 \%$ the interval of confidence for $r=r_{\max }$ equals to $0,969 \pm 0,038, p=1,30$, and for steel $10 \mathrm{MnH} 2 \mathrm{MoV}$ the interval of confidence $0,927 \pm 0,026, p=1,59$.

The summarized curve of deformation was constructed by the points $\left(\left(\varepsilon_{e q}\right)_{i},\left(\sigma_{e q}\right)_{i}\right)$, which were obtained for the optimum parameter $\mathrm{p}$. The area of strengthening was approximated by the degree model $\sigma_{e q}=A \varepsilon_{e q}{ }^{B}$. We have obtained:

$$
\begin{gathered}
\tilde{\sigma}_{e q}=874,32 \cdot \varepsilon_{e q}^{0,2745} \quad \text { (for steel 45), } \\
\tilde{\sigma}_{e q}=771,01 \cdot \varepsilon_{e q}^{0,1315} \quad \text { (for steel 10MnH2MoV). }
\end{gathered}
$$

Study outcomes. Having calculated the values of true circular and axial stresses by formulae $\left(\tilde{\sigma}_{z}\right)_{i}=\left(\sigma_{z}\right)_{i}\left(1+\left(\varepsilon_{z}\right)_{i}\right),\left(\tilde{\sigma}_{\theta}\right)_{i}=\left(\sigma_{\theta}\right)_{i}\left(1+\left(\varepsilon_{\theta}\right)_{i}\right)^{2}$, and also true equivalent stresses $\left(\tilde{\sigma}_{e q}\right)_{i}=\frac{p}{2}\left[\frac{\left|\left(\tilde{\sigma}_{z}\right)_{i}-\left(\tilde{\sigma}_{\theta}\right)_{i}\right|^{p}+\left|\left(\tilde{\sigma}_{\theta}\right)_{i}\right|^{p}+\left|\left(\tilde{\sigma}_{z}\right)_{i}\right|^{p}}{2}\right]^{\frac{1}{p}}$, , the equation of true curve of deformation was obtained $\tilde{\sigma}_{e q}\left(\varepsilon_{e q}\right)$. True stress-state curves and experimental points, equations of degree regression and determination coefficient are given on fig. 1.

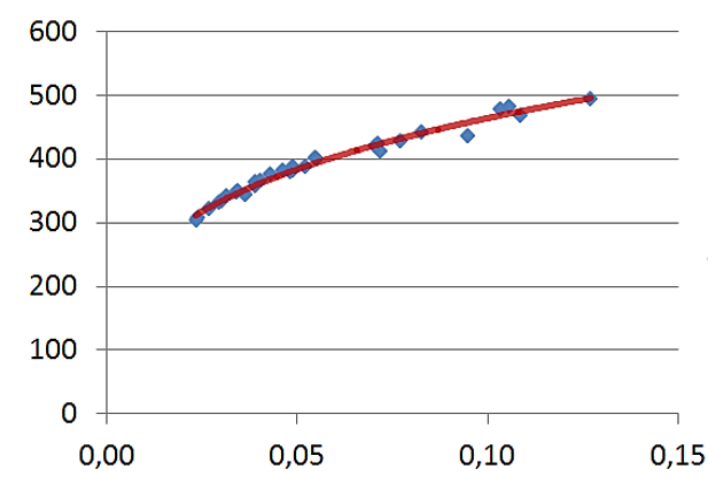

a)

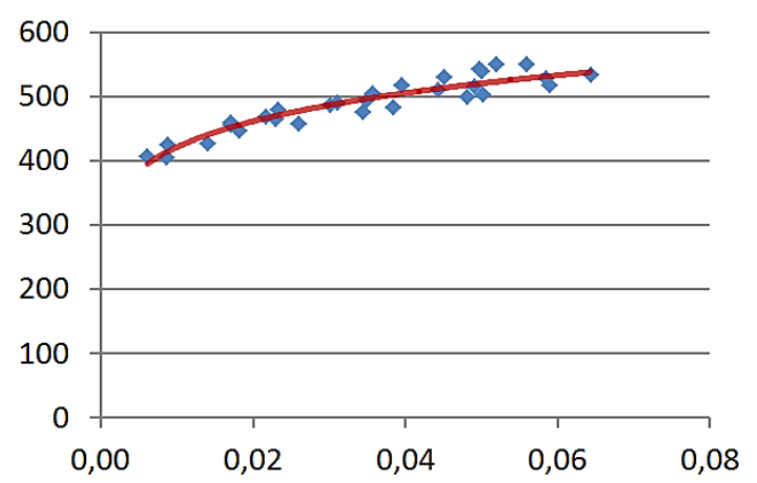

b)

Figure 1. Approximation of a true stress-strain curve and determination coefficient for
a) steel $45 y=874,32 x^{0.2745} R^{2}=0,9831$; b)
; b) steel $10 \mathrm{MnH} 2 \mathrm{MoV}$ $y=771,01 x^{0.1315}$
$R^{2}=0,896$ 
To solve the equation (1) and to find the true ultimate stresses in the system of coordinates $\left(\varepsilon_{e q} ; \tilde{\sigma}_{e q}\right)$ the graphs of both sides of the equations have been constructed. At k >>2 the pipe stress-and-strain state is close to the uniaxial one, so on the figures the calculations results are given for the interval which is important in practical engineering, $k \in(0,5 ; 2)$.

As a degree model was chosen for the analytical description of stress-strain curve, then the derivative $d \tilde{\sigma}_{e q} / d \varepsilon_{e q}$ was defined by the formula $d \tilde{\sigma}_{e q} / d \varepsilon_{e q}=A \cdot B \cdot \varepsilon_{e q}{ }^{B-1}$. From (5) and (6) the expression was obtained which made possible to find tangent moduli:

$$
\begin{gathered}
\frac{d \tilde{\sigma}_{e q}}{d \varepsilon_{e q}}=240,0 \cdot \varepsilon_{e q}^{-0,7255} \\
\text { (for steel), } \\
\frac{d \tilde{\sigma}_{e q}}{d \varepsilon_{e q}}=101,4 \cdot \varepsilon_{e q}^{-0,8685} \quad \text { (for steel 10MnH2MoV). }
\end{gathered}
$$

Graphical solution of equation ( 1 ) for $h / R=0,08$, where $R=(d-h) / 2$ - radius of the pipe middle surface is given on fig. 2 . The value $\mu$ has been calculated by the formula obtained in [16] by the known values $\mathrm{p}, \mathrm{k}, \mathrm{h}, \mathrm{R}$. Solid curves show the true generalized stress-strain curves constructed at optimal values of the parameter $\mathrm{p}$ for each of the materials. True generalized stress-strain curve is a graph representation of the equation left-hand side (1). Curves of the equation (1) right-hand side are given as dotted graphs - the product of tangent modulus and correcting multiplier $\mu$ taking into account the geometry of a pipe loaded by internal pressure and tension at the moment when local plastic deformations appeared.

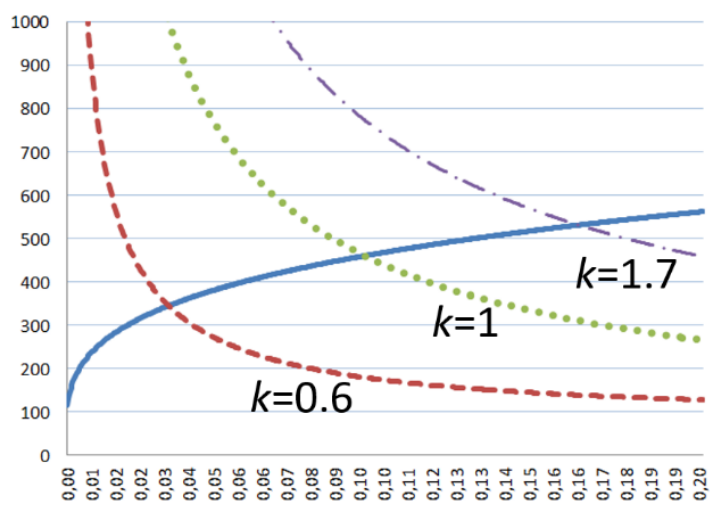

a)

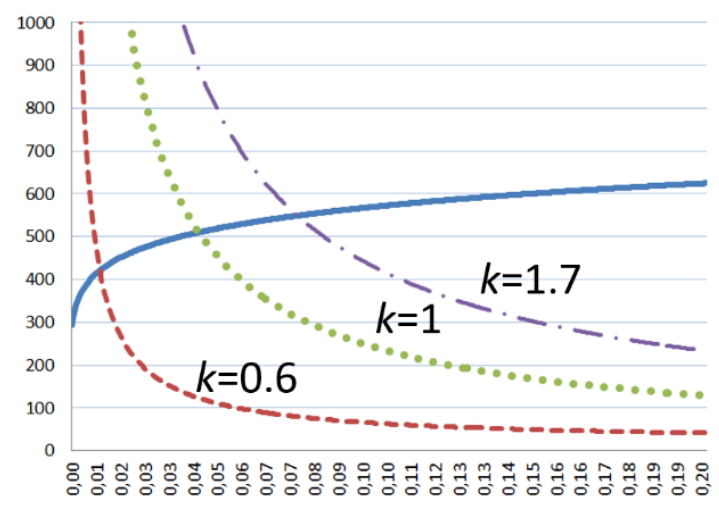

b)

Figure 2. Graphical solution of equation (1) for thin-walled pipes made of a) steel 45 ; b) steel $10 \mathrm{MnH} 2 \mathrm{MoV}$. A solid line is a true generalized stress-strain curve

Fig. 2 shows that the type of stressed state k makes a great impact on the pipe durability.

The curves of limiting true equivalent stresses $\tilde{\sigma}_{e q}$ dependence on $\mathrm{k}$ for several $\mathrm{h} / \mathrm{R}$ are shown on fig. 3 


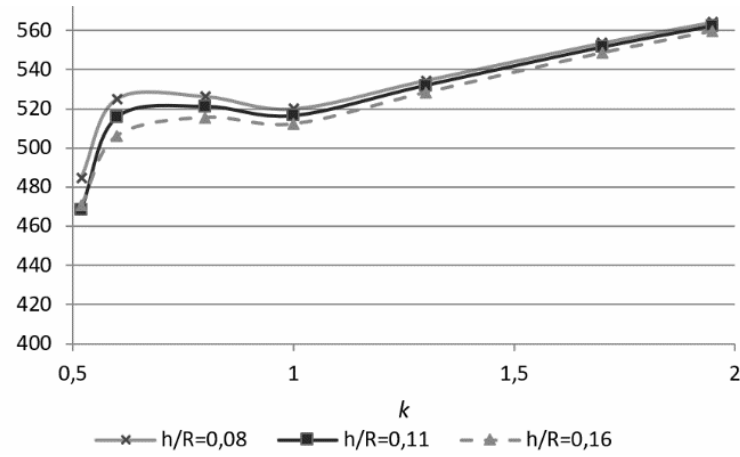

a)

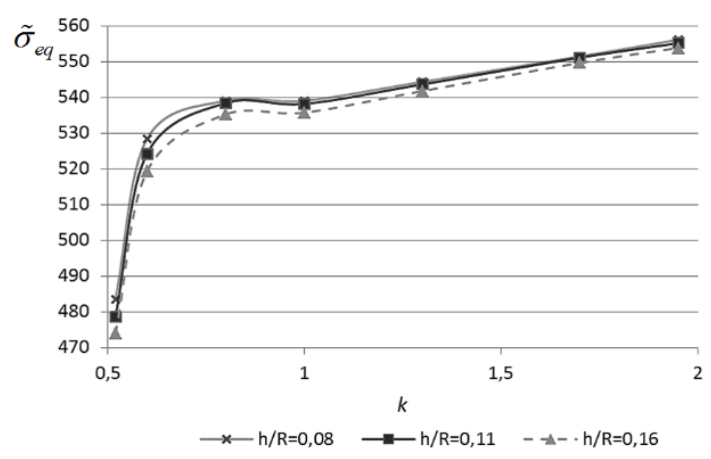

b)

Figure 3. Dependence of limit stresses $\tilde{\sigma}_{e q}$ on k for certain h/R a) steel 45; b) steel 10MnH2MoV. A solid line is a true generalized stress-strain curve

Fig. 3 shows that the smallest calculated durability occurs when pipe is loaded only by internal pressure $(\mathrm{k}=0,5)$. Under stress state with a coefficient $\mathrm{k}=0,5 \ldots 1$ the uniform plastic stability loss occurs at higher values of true equivalent stresses for all patterns, the pipe durability is getting higher. The increase of $\mathrm{h} / \mathrm{R}$ from 0,08 to 0,11 for $\mathrm{k}=0,6 . .0,7$ makes the calculated ultimate values of true equivalent stresses $10 \mathrm{MPa}$ ( or $\approx 2 \%$ ) lower on average. In pipes of smaller parameter $\mathrm{h} / \mathrm{R}$ the higher level of calculated true equivalent stresses has been found at the moment of deformation localization. At $\mathrm{k}=1$ the increase of correlation $\mathrm{h} / \mathrm{R}$ from 0,08 to 0,11 results in average $5 \mathrm{MPa}$ ( or $\approx 1 \%$ ) decrease of calculated true ultimate equivalent stresses for steel 45 . For steel $10 \mathrm{MnH} 2 \mathrm{MoV}$ the level of limit equivalent stresses at the correlations $h / R=0,08$ and $h / R=0,11$ is the same. Under further increase conditions of correlation $\mathrm{h} / \mathrm{R}$ from 0,11 to 0,16 the limit calculated equivalent stresses are $1-1,5 \%$ smaller for both materials.

Dependence $\tilde{\sigma}_{e q}$ on the type of stressed state at $k=1 . .2$ is close to the linear one for all chosen values $\mathrm{h} / \mathrm{R}$.

The dependencies of calculated ultimate values of true circular and axial stresses under combined loading conditions of the pipe by internal pressure and tension for both steel grades are shown on fig. 4. The graphs allow to imagine the character of dependence of limit true circular and axial stresses on $\mathrm{k}$ in the interval $(0,5 ; 2)$ taking into account the patterns geometry. Separate symbols denote the points corresponding the engineering ultimate values of stresses for steel 45 at three types of stressed state $(\mathrm{k}=0,5 ; 1 ; 2)$. In case of pipe loading only with internal pressure the calculated ultimate true axial stress coincides with the referencing one. This phenomenon can be explained by zero axial deformations. The engineering ultimate values of stresses are much lower than true calculated ones. For $\mathrm{k}=1$ the calculated true stresses are 1,2-1,3 higher than referencing ones, and for $\mathrm{k}=2-1,1-1,2$ higher. The two times increase of thin wall index (from 0,08 to 0,16 ) results in $4-5 \%$ decrease of the level of maximum calculated ultimate circular stresses (for $\mathrm{k}=0,6$ ). The dependence for steel $10 \mathrm{MnH} 2 \mathrm{MoV}$ is the same as the previous one. The two times increase of thin wall index (from 0,08 to 0,16 ) results in $2-3 \%$ decrease of the level of maximum calculated ultimate circular stresses (at $\mathrm{k}=0,6$ ). 


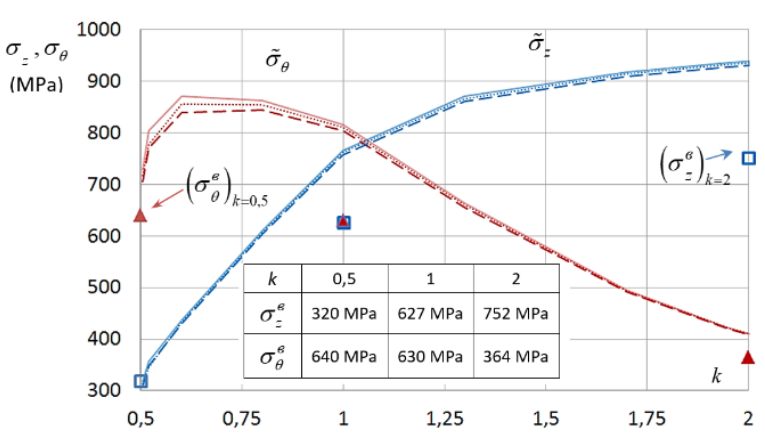

a)

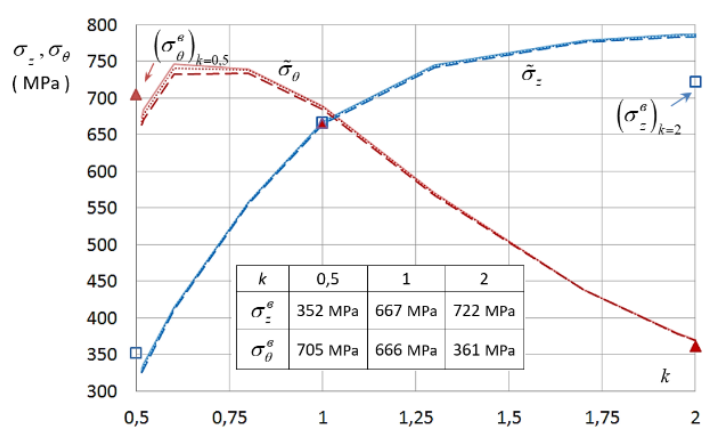

b)

Figure 4. Dependence of limit values of calculated stresses on $k$ for certain $h / R$. Denoted: _ _ $-\mathrm{h} / \mathrm{R}=0,08 ; \ldots \ldots . . . \mathrm{h} / \mathrm{R}=0,11 ; \ldots \ldots . \mathrm{h} / \mathrm{R}=0,16$. Separate points show the engineering strength limits for $\mathrm{k}=0,5 ; 1 ; 2$

Fig. 4 proves that for $k=1$ the calculated true ultimate circular stresses are on average $1,01 . .1,3$ times higher than engineering ones, the true ultimate axial stresses are on average $1,1 . .1,2$ times higher than engineering ones. The two times increase of $\mathrm{h} / \mathrm{R}$ (from 0,08 to 0,16 ) makes the level of calculated ultimate stresses 1-3\% lower.

It shows the importance of improvement of strength properties of structural elements not only due to their mass increase.

Conclusions. The influence of stress state type and thin-walled cylinder geometry on the ultimate values of true stresses at the moment of the uniform plastic stability loss has been analyzed. The ratio $\mathrm{h} / \mathrm{R}$ increase to some extent allows the ultimate values of axial strain and internal pressure be increased for both materials. Though the further increase of ratio $h / R$ increases the allowable value of internal pressure but makes the maximum allowable values of strains lower. This fact proves the existence of optimal balance between the pipe geometry and its strength. The above-mentioned results can be used for calculation of loaded thin-walled pipes aimed at their material consumption saving, safety level increase under performance conditions and choose real safety factor.

\section{References}

1. Luchko J., Ivanyk E. Ciagnostics of the main gas pipelines and assessment of their residual life under the conditions of long-term operation. Scientific Journal of TNTU (Tern.) 2017, vol. 87, no. 3, pp. 48-63. DOI: https://doi.org/10.33108/visnyk_tntu2017.03.048

2. Bony, M., Alamilla, J. L., Vai, R., Flores, E. Failure pressure in corroded pipelines based on equivalent solutions for undamaged pipe. ASME. J. Pressure Vessel Technol. 2010, 132 (5): 051001. DOI: https://doi.org/10.1115/1.4001801

3. Hillier M. J. Tensile plastic instability of thin tubes-I. International Journal of Mechanical Sciences, Vol. 7. Issue 8, 1965. pp. 531-538, ISSN 0020-7403. DOI: https://doi.org/10.1016/0020-7403(65)90010-X

4. Tomita Y., Shindo A., Nagai M. Axisymmetric deformation of circular elastic-plastic tubes under axial tension and internal pressure. International Journal of Mechanical Sciences. Volume 26. Issues 6-8. 1984. P. 437-444. ISSN 0020-7403. DOI: https://doi.org/10.1016/0020-7403(84)90033-X

5. Dilman, V. L., Ostsemin A. A. O vliyanii dvuhosnosti nagrujeniya na nesuschuyu sposobnost trub magistralnyih gazonefteprovodov Izv. RAN. Mehanika tverdogo tela, 2000. No. 5, pp. 179-185. [In Russian].

6. Dilman, V. L., Ostsemin, A. A. O potere plasticheskoy ustoychivosti tonkostennyih tsilindricheskih obolochek. Problemyi mashinostroeniya i nadejnosti mashin. 2000. No. 5, pp. 50-57. [In Russian].

7. Degtyarev V. P. Deformatsii i razrushenie v vyisokonapryajennyih konstruktsiyah. M.: Mashinostroenie, 1987. 105 p. [In Russian].

8. Kollinz Dj. Povrejdenie materialov v konstruktsiyah. Analiz, predskazanie, predotvraschenie. M.: Mir, 1984. 624 p. [In Russian].

9. Updike D. P., Kalnins A. Tensile plastic instability of axisymmetric pressure vessels. ASME. J. Pressure Vessel Technol, 120 (1), February 1998. P. 6-11. DOI: https://doi.org/10.1115/1.2841888 
10.Zhu, Xian-Kui \& Leis, Brian. (2011). Evaluation of burst pressure prediction models for line pipes. International Journal of Pressure Vessels and Piping - INT J PRESSURE VESSELS PIPING. P. 89. DOI: https://doi.org/10.1016/j.ijpvp.2011.09.007

11. Law, M. (2005). Use of the cylindrical instability stress for blunt metal loss defects in linepipe. International Journal of Pressure Vessels and Piping, 82 (12), 925-928. DOI: https://doi.org/10.1016/j.ijpvp.2005.04.002

12. Kozbur H. Prediction technique for thin-walled cylindrical tubes boundary state. Scientific Journal of TNTU. Tern: TNTU, 2019. Vol. 94. No. 2. P. 145-155. (Mathematical modeling. Mathematics). DOI: https://doi.org/10.33108/visnyk_tntu2019.02.145

13. Kozbur H. Method of predicting necking true stress in a thin-walled tube under a complex stress state. Strojnícky časopis. Journal of Mechanical Engineering. 2020. No. 70 (2), 101-116. DOI: https://doi.org/10.2478/scjme-2020-0024

14. Kaminskiy A. A., Bastun V. N. Deformatsionnoe uprochnenie i razrushenie metallov pri peremennyih protsessah nagrujeniya. K.: Nauk.dumka, 1985. 168 p. [In Russian].

15. Lebedev A. A., Kovalchuk B. I., Giginyak F. F., Lamashevskiy V. P. Mehanicheskie svoystva konstruktsionnyih materialov pri slojnom napryajennom sostoyanii. Pod red. akademika NAN Ukrainyi A. A. Lebedeva. Kiev: Izdatelskiy dom "In YUre", 2003. 540 p. [In Russian].

\section{Список використаної літератури}

1. Luchko J., Ivanyk E. Diagnostics of the main gas pipelines and assessment of their residual life under the conditions of long-term operation. Scientific Journal of TNTU (Tern.), 2017, vol. 87, no. 3, pp. 48-63. [In English]. DOI: https://doi.org/10.33108/visnyk_tntu2017.03.048

2. Bony, M., Alamilla, J. L., Vai, R., Flores, E. Failure pressure in corroded pipelines based on equivalent solutions for undamaged pipe. ASME. J. Pressure Vessel Technol. 2010; 132 (5): 051001. DOI: https://doi.org/10.1115/1.4001801

3. Hillier M. J. Tensile plastic instability of thin tubes-I. International Journal of Mechanical Sciences. Vol. 7. Issue 8. 1965. P. 531-538. ISSN 0020-7403. DOI: https://doi.org/10.1016/0020-7403(65)90010-X

4. Tomita Y., Shindo A., Nagai M. Axisymmetric deformation of circular elastic-plastic tubes under axial tension and internal pressure. International Journal of Mechanical Sciences. Volume 26. Issues 6-8. 1984. P. 437-444. ISSN 0020-7403. DOI: https://doi.org/10.1016/0020-7403(84)90033-X

5. Дильман В. Л., Остсемин А. А. О влиянии двухосности нагружения на несущую способность труб магистральных газонефтепроводов. Изв. РАН. Механика твердого тела. 2000. № 5. С. 179-185.

6. Дильман В. Л., Остсемин А. А. О потере пластической устойчивости тонкостенных цилиндрических оболочек. Проблемы машиностроения и надежности машин. 2002. № 5. С. 50-57.

7. Дегтярев В.П. Деформации и разрушение в высоконапряженных конструкциях. М.: Машиностроение, 1987. 105 с.

8. Коллинз Дж. Повреждение материалов в конструкциях. Анализ, предсказание, предотвращение. М.: Мир, 1984. 624 c.

9. Updike D. P., Kalnins A. Tensile plastic instability of axisymmetric pressure vessels. ASME. J. Pressure Vessel Technol, 120 (1), February 1998. P. 6-11. DOI: https://doi.org/10.1115/1.2841888

10. Zhu, Xian-Kui \& Leis, Brian. (2011). Evaluation of burst pressure prediction models for line pipes. International Journal of Pressure Vessels and Piping - INT J PRESSURE VESSELS PIPING. P. 89. DOI: https://doi.org/10.1016/j.ijpvp.2011.09.007

11. Law M. Use of the cylindrical instability stress for blunt metal loss defects in linepipe. International Journal of Pressure Vessels and Piping, 2005, 82 (12), 925-928. DOI: https://doi.org/10.1016/j.ijpvp.2005.04.002

12. Kozbur H. Prediction technique for thin-walled cylindrical tubes boundary state. Scientific Journal of TNTU. Tern: TNTU, 2019. Vol. 94. No. 2. P. 145-155. (Mathematical modeling. Mathematics). DOI: https://doi.org/10.33108/visnyk_tntu2019.02.145

13. Kozbur H. Method of predicting necking true stress in a thin-walled tube under a complex stress state. Strojnícky časopis. Journal of Mechanical Engineering. 2020. № 70 (2). P. 101-116. DOI: https://doi.org/10.2478/scjme-2020-0024

14. Каминский А. А., Бастун В. Н. Деформационное упрочнение и разрушение металлов при переменных процессах нагружения. К.: Наук.думка, 1985. 168 с.

15. Лебедев А. А., Ковальчук Б. И., Гигиняк Ф. Ф., Ламашевский В. П. Механические свойства конструкционных материалов при сложном напряженном состоянии: под ред. академика НАН Украины А. А. Лебедева. Киев: Издательский дом «Ин Юре», 2003. 540 с. 


\title{
УДК 539.4
}

\section{ЧИСЕЛЬНЕ ПРОГНОЗУВАННЯ МІЦНОСТІ ТОНКОСТІННОЇ ТРУБИ, НАВАНТАЖЕНОЇ ВНУТРІШНІМ ТИСКОМ ТА ОСЬОВИМ РОЗТЯГОМ, ІЗ УРАХУВАННЯМ ЇЇ ФАКТИЧНИХ РОЗМІРІВ}

\author{
Галина Козбур; Олег Шкодзінський; Леся Дмитроца
}

\author{
Тернопільський начіональний технічний університет імені Івана Пулюя, \\ Тернопіль, Україна
}

\begin{abstract}
Резюме. В реальних експлуатачійних умовах трубопроводи та ємності, навантажені внутрішнім тиском, можуть також зазнавати осьових навантажень, спричинених позаштатними факторами, наприклад дією температури, гірськими умовами, рухомістю грунтів, тощо. Тому важливим є вивчення напружено-деформованого стану труб та ємностей в умовах комбінованого навантаження. Досліджено дійсний напружений стан тонкостінних труб, щзо зазнають пластичних деформацій в умовах монотонного статичного навантаження внутрішнім тиском та осьовим розтягом. Утворення локальних пластичних деформацій вважається в роботі ознакою досягнення границі міцності. Методику прогнозування граничних значень дійсних напружень у момент локалізачії рівномірних пластичних деформацій розроблено на основі критерію втрати стійкості процесу пластичного деформування Свіфта-Мариіньяка та приничипу максимуму навантаження. Методикою враховано фізико-механічні властивості матеріалу, фактичні розміри навантажених конструкційних елементів та вид напруженого стану. Наведено алгоритм методики. Інженерну реалізацію методики виконано для труб, виготовлених із двох марок сталей (сталі 45 та сталі 10ГН2МФА) різної геометрії. Проаналізовано вплив виду напруженого стану та геометрії тонкостінних труб на граничні значення дійсних напружень у момент появи локальних деформаиій. Виконано графічний аналіз отриманих залежностей. Показано, щчо можливе встановлення балансу між фактичною геометрією елемента та навантаженням, яке дозволить вирішити завдання пошуку оптимального співвідношення «вага-міиність», важливого для практичних застосувань в авіа-, ракето- та машинобудуванні. Результати можна застосовувати для розрахунку навантажених тонкостінних труб з метою зменшення їх матеріалоємності, підвищення рівня безпеки та ефективності в експлуатації, а також обгрунтовувати визначення коефіцієнта запасу та приймати удосконалені інженерно-конструкторські рішення на етапах проектування та експлуатації трубчастих елементів конструкиій.
\end{abstract}

Ключові слова: локалізачџія деформачій, втрата стійкості пластичного деформування, тонкостінна труба, дійсні напруження. 